\title{
THE PREPARATION OF THE BIOSYNTHETIC PRECURSOR 3,7-DIHYDROXY-2,6-DIMETHOXYPHENANTHROINDOLIZIDINE
}

\author{
Kinuko Iwasa, * Miyoko Kamigauchi, Narao TakaO, \\ Kobe Women's College of Pharmacy, 4-19-1, Motoyamakita-machi, Higashinada-ku, Kobe 658, Japan \\ and WOLFGANG WIEGREBE
}

Institute for Pharmaceutical Chemistry, University of Regensburg, D-8400 Regensburg, Federal Republic of Germany

In order to set the stage for a study of the biosynthesis of tylophorine [7] and related phenanthroindolizidine alkaloids using callus tissues from Cynanchum vincetoxicum (L.) Pers. Asclepiadaceae, there was a need to prepare the key biogenetic precursor 3,7-dihydroxy-2, 6-dimethoxynanthroindolizidine [6].

This diphenol was synthesized by a route paralleling those described by Herbert et al. (1) and Ban and Oishi (2) (Scheme 1). The known 3-benzyloxy-4methoxyphenylacetaldehyde [1] prepared by a procedure comparable to that of Ban and Oishi (2) was condensed with the pyrrolidine 2 , which had been obtained by a route related to that of Herbert et al. (1). The condensation product was immediately reduced with $\mathrm{NaBH}_{4}$ to provide the indolizidine 3 . This material was further characterized through its diphenolic derivative $\mathbf{4}$ obtained through acid hydrolysis.

Indolizidine $\mathbf{3}$ suffered intramolecular oxidative coupling upon treatment with thallium(III)trifluoroacetate in MeCN containing a catalytic amount of boron trifluoride etherate to produce the pentacyclic phenanthroindolizidine $\mathbf{5}$. Acid hydrolysis of $\mathbf{5}$ then supplied the desired 3,7-dihydroxy-2,6-dimethoxyphenanthroindolizidine [6].

Each of our new compounds was characterized spectrally using high resolution $\mathrm{nmr}$ as well as ms.

As final proof of structure, the diphenol 6 was $O$-methylated with ethereal $\mathrm{CH}_{2} \mathrm{~N}_{2}$ to provide (士)tylophorine [7], spectroscopically identical with an authentic sample.

\section{EXPERIMENTAL}

GENERAL EXPERIMENTAL PROCEDURES.Melting points are uncorrected. Uv spectra were recorded on a UVIKON 810 using $\mathrm{MeOH}$ as solvent. Ir spectra were recorded on a Beckman Acculab 3 spectrophotometer. ${ }^{1} \mathrm{H}$-nmr spectra were obtained on a Varian EM 390 or Varian XL-200 or Bruker WM 250 spectrometer. Chemical shifts are reported in ppm relative to TMS as an internal standard. Except where noted, the sample for ${ }^{1} \mathrm{H}$-nmr analyses was dissolved in $\mathrm{CDCl}_{3}$. Mass spectra were determined on a Varian MAT $\mathrm{CH} 7$ or a Hitachi M80 at $70 \mathrm{eV}$. Isobutane gas was used in the cims. High resolution mass spectra were obtained on a Hitachi M80 or Varian MAT 311A. Preparative tlc was on Si gel 60 F254 Merck glass plates.

PREPARATION OF 3-BENZYLOXY-4-METHOXYPHENYL ACETALDEHYDE [1].- Sodium 3-(3benzyloxy-4-methoxyphenyl)glycidate was prepared starting from isovanillin according to the procedure described by Ban and Oishi (2). To a suspension of sodium glycidate $(22 \mathrm{~g})$ in dry $\mathrm{C}_{6} \mathrm{H}_{6}(280 \mathrm{ml})$ was added HOAc $(5.6 \mathrm{ml})$; the mixture was stirred and refluxed gently for $3 \mathrm{~h}$. After cooling the $\mathrm{C}_{6} \mathrm{H}_{6}$ solution was washed with $\mathrm{H}_{2} \mathrm{O}$, dried, and evaporated. The residue was dissolved in $\mathrm{Et}_{2} \mathrm{O}(300 \mathrm{ml})$, and the $\mathrm{Et}_{2} \mathrm{O}$ solution was stirred vigorously with a solution of $\mathrm{NaHSO}_{3}$ (12 g) in $\mathrm{H}_{2} \mathrm{O}(24 \mathrm{ml})$ overnight. The bisulfite adduct precipitated was filtered, washed with $\mathrm{Et}_{2} \mathrm{O}$, and dried $(21 \mathrm{~g})$. This adduct $(11 \mathrm{~g})$ was suspended in saturated $\mathrm{NaHCO}_{3}(150 \mathrm{ml})$, extracted with $\mathrm{Et}_{2} \mathrm{O}$, dried, and evaporated to obtain the free aldehyde $1(5.8 \mathrm{~g}, 74 \%$; the yield from sodium glycidate is $60 \%)$, ir $\left(\mathrm{CHCl}_{3}\right) v$ max $1730 ;{ }^{1} \mathrm{H} \mathrm{nmr} \delta 3.45\left(2 \mathrm{H}, \mathrm{d}, J=2.2 \mathrm{~Hz}, \mathrm{CH}_{2}\right.$ $\mathrm{CHO}), 3.81(3 \mathrm{H}, \mathrm{s}, \mathrm{OMe}), 5.09(2 \mathrm{H}, \mathrm{s}$, $\left.\mathrm{OCH}_{2} \mathrm{Ph}\right), 6.55-6.85$ (3H, m, Ar-H), 7.0-7.40 ( $5 \mathrm{H}, \mathrm{m}, \mathrm{Ar}-\mathrm{H}), 9.60(1 \mathrm{H}, \mathrm{t}, J=2.2 \mathrm{~Hz}, \mathrm{CHO})$. The aldehyde $(500 \mathrm{mg}$ ) was dissolved in $\mathrm{EtOH}$ $(10 \mathrm{ml})$ and refluxed gently with a $0.1 \mathrm{M}$ solution (20 $\mathrm{ml})$ of 2,4-dinitrophenylhydrazine (prepared from $2.0 \mathrm{~g}$ of 2,4-dinitrophenylhydrazine, $50 \mathrm{ml}$ of $85 \% \mathrm{H}_{3} \mathrm{PO}_{4}$, and $50 \mathrm{ml}$ of $\mathrm{EtOH}$ ) for $15 \mathrm{~min}$. Upon cooling the crystallized hydrazone was 
<smiles>COc1ccc(CC=O)cc1OCc1ccccc1</smiles>

1<smiles>COc1ccc(C2=C(c3ccc(OCc4ccccc4)c(OC)c3)CN3CCCC3C2)cc1</smiles><smiles>COc1cc2c3c(c4cc(O)c(OC)cc4c2cc1O)CN1CCCC1C3</smiles>

SCHEME 1

filtered and recrystallized from $\mathrm{C}_{6} \mathrm{H}_{6}(500 \mathrm{mg}$, $74 \%$ ), mp $149-150^{\circ}$ [lit. (3) $\mathrm{mp} 151-152^{\circ}$ \}; ir (Nujol) $v$ max $3275(\mathrm{NH}), 1630(\mathrm{C}=\mathrm{N}) ;{ }^{1} \mathrm{H} \mathrm{nmr}$ $\delta 3.60\left(2 \mathrm{H}, \mathrm{d}, J=6.0 \mathrm{~Hz}, \mathrm{CH}_{2}-\mathrm{CH}=\mathrm{N}\right), 3.87$ $(3 \mathrm{H}, \mathrm{s}, \mathrm{OMe}), 5.14\left(2 \mathrm{H}, \mathrm{s}, \mathrm{OCH}_{2} \mathrm{Ph}\right), 6.7-6.85$ $(2 \mathrm{H}, \mathrm{m}, \mathrm{Ar}-\mathrm{H}), 6.82(1 \mathrm{H}, \mathrm{s}, \mathrm{Ar}-\mathrm{H}), 7.15-7.45$ $(6 \mathrm{H}, \mathrm{m}, \mathrm{Ar}-\mathrm{H}), 7.90(1 \mathrm{H}, \mathrm{d}, J=9.0 \mathrm{~Hz}, \mathrm{Ar}-\mathrm{H})$, $8.29(1 \mathrm{H}, \mathrm{dd}, J=9.0,2.0 \mathrm{~Hz}, \mathrm{Ar}-\mathrm{H}), 9.1(1 \mathrm{H}$, $\mathrm{d}, J=2.0 \mathrm{~Hz}, \mathrm{Ar}-\mathrm{H}), 10.9(1 \mathrm{H}, \mathrm{s}, \mathrm{NH}) ; \mathrm{ms} m / z$ (rel. int.) $[\mathrm{M}]^{+} 436(5), 91(100)$.

PRePARATION OF 2-(4-BENZYLOXY-3-METHOXYPHENANCYL)PYRROLIDINE [2].-Starting from vanillic acid, the procedure of Herbert $e t$ al. (1) for the preparation of 4-benzyloxy-3- methoxybenzoylacetic acid was used. The crude benzoylacetic acid $(9.6 \mathrm{~g})$ was dissolved in $\mathrm{MeOH}$ ( $450 \mathrm{ml}$ ), and phosphate buffer $(45 \mathrm{ml}, 1 \mathrm{M}, \mathrm{pH}$ 7.2) was added to a solution of 1-pyrroline (4) [freshly prepared from DL-ornithine monohydrochloride $(5.36 \mathrm{~g})$ and $\mathrm{N}$-bromosuccinimide (5.6 g)]. The $\mathrm{pH}$ was ajusted to $7.0(1 \mathrm{M} \mathrm{KOH})$, and the reaction mixture was stirred under $\mathrm{N}_{2}$ for $46 \mathrm{~h}$ at room temperature. The resulting mixture was concentrated under reduced pressure at $50^{\circ}$, and the precipitated material was filtered off. The solution was acidified with $10 \% \mathrm{HCl}$ and extracted with $\mathrm{Et}_{2} \mathrm{O}$. The aqueous acidic solution was basified with $\mathrm{K}_{2} \mathrm{CO}_{3}$ and extracted with $\mathrm{Et}_{2} \mathrm{O}$ and then with $\mathrm{CHCl}_{3}$. Each extract was dried, and the 
solvent was removed. The residues from the $\mathrm{Et}_{2} \mathrm{O}$ and $\mathrm{CHCl}_{3}$ extracts were dissolved in $\mathrm{MeOH}$ $(100 \mathrm{ml}), 37 \% \mathrm{HCl}(0.1 \mathrm{ml})$ was added, the solvent was removed, and both residues were crystallized from $\mathrm{Me}_{2} \mathrm{CO}$ to give the hydrochloride of $\mathbf{2}$ (3.0 $\mathrm{g}$ and $0.44 \mathrm{~g}$, respectively, $52 \%$ ), $\mathrm{mp} 177-$ $180^{\circ}$ (dec); ir (Nujol) $v$ max 2710-2300 $(\rightarrow \stackrel{+}{\mathrm{N}}-$ $\left.\mathrm{H}_{2}\right), 1680(\mathrm{C}=\mathrm{O}) ;{ }^{1} \mathrm{H} \mathrm{nmr} \delta 1.4-2.4(4 \mathrm{H}, \mathrm{m})$, $3.1-3.5(3 \mathrm{H}, \mathrm{m}), 3.6-4.3(2 \mathrm{H}, \mathrm{m}), 3.84(3 \mathrm{H}, \mathrm{s}$, $\mathrm{OMe}), 5.10\left(2 \mathrm{H}, \mathrm{s}, \mathrm{OCH}_{2} \mathrm{Ph}\right), 6.76(1 \mathrm{H}, \mathrm{d}$, $J=9.0 \mathrm{~Hz}, \mathrm{Ar}-\mathrm{H}), 7.2-7.5(7 \mathrm{H}, \mathrm{m}, \mathrm{Ar}-\mathrm{H}), 9.6$ $\left(2 \mathrm{H}\right.$, br, $\left.\mathrm{NH}_{2}\right)$. Free base [2]: ir (film) $v$ max 3340 (br, NH), $1678(\mathrm{C}=\mathrm{O}) ;{ }^{1} \mathrm{H}$ nmr $\delta 2.10$ (1H, br s, NH), 1.2-2.5 (4H, m), 2.7-3.1 (4H, $\mathrm{m}), 3.5(1 \mathrm{H}, \mathrm{m}), 3.92(3 \mathrm{H}, \mathrm{s}, \mathrm{OMe}), 5.20(2 \mathrm{H}$, s, $\left.\mathrm{OCH}_{2} \mathrm{Ph}\right), 6.87(1 \mathrm{H}, \mathrm{d}, J=9.0 \mathrm{~Hz}, \mathrm{Ar}-\mathrm{H})$, 7.2-7.45 (6H, m, Ar-H), $7.50(1 \mathrm{H}, \mathrm{s}, \mathrm{Ar}-\mathrm{H})$; ms $\mathrm{m} / z$ (rel. int.) $[\mathrm{M}]^{+} 325$ (0.2), 256 (6.5), 91 (100); cims $m / z[\mathrm{M}+1]^{+} 326$.

PREPARATION OF 6-(3-BENZYLOXY-4-METHOXY)-7-(4-BENZYLOXY-3- METHOXYPHENYL)1,2,3,5,8,8a-HEXAHYDROINDOLIZINE [3].3-Benzyloxy-4-methoxyphenylacetaldehyde [1] (375 mg) and 2-(4-benzyloxy-3-methoxyphenyl)pyrrolidine [2] $(320 \mathrm{mg})$ were stirred in dry $\mathrm{C}_{6} \mathrm{H}_{6}$ $(15 \mathrm{ml})$ for $1 \mathrm{~h}$ at room temperature. The solvent was removed under pressure, and the residue was dissolved in dry $\mathrm{MeOH}$ (15 ml). The solution was stirred at room temperature for $1 \mathrm{~h}$. $\mathrm{NaBH}_{4}(90$ $\mathrm{mg}$ ) was added to the $\mathrm{MeOH}$ solution, and the mixture was stirred for $1 \mathrm{~h}$. The precipitate was collected and recrystallized from $\mathrm{CHCl}_{3} / \mathrm{MeOH}$ to give 3 (125 mg, 23\%), mp 133-134 [lit. (5) mp 131-132 ]; uv $\lambda \max (\mathrm{MeOH}) \log \epsilon) 281$ (2.94), $230(\mathrm{sh}) ;{ }^{1} \mathrm{H} \mathrm{nmr} \delta 1.5-2.9(8 \mathrm{H}, \mathrm{m})$, $3.26(1 \mathrm{H}, \mathrm{m}), 3.20$ and 3.75 (each $1 \mathrm{H}, \mathrm{d}$, $J=15.5 \mathrm{~Hz},=\mathrm{C}-\mathrm{CH}_{2}-\mathrm{N}$ ), 3.57 and 3.75 (each $3 \mathrm{H}, \mathrm{s}, 2 \times \mathrm{OMe}$ ), 4.80 and 5.05 (each $2 \mathrm{H}$, s, $\left.2 \times \mathrm{OCH}_{2} \mathrm{Ph}\right), 6.45-6.85(6 \mathrm{H}, \mathrm{m}, \mathrm{Ar}-\mathrm{H}), 7.2-$ $7.5(10 \mathrm{H}, \mathrm{m}, \mathrm{Ar}-\mathrm{H})$.

PREPARATION OF 6-(3-HYDROXY-4-METHOXYPHENYL)-7-(4-HYDROXY-3-METHOXYPHENYL)$1,2,3,5,8,8 \mathrm{a}-$ HEXAHYDROINDOLIZINE [4].The reaction of the pyrrolidine $\mathbf{2}$ (from $\mathbf{2} \cdot \mathrm{HCl}$ salt $2.37 \mathrm{~g}$ ) with the aldehyde $\mathbf{1}(1.6 \mathrm{~g})$ followed by $\mathrm{NaBH}_{4}$ reduction was carried out as described above. After reduction the $\mathrm{MeOH}$ was removed, $\mathrm{H}_{2} \mathrm{O}$ was added to the residue, and it was extracted with $\mathrm{CHCl}_{3}$. Combined $\mathrm{CHCl}_{3}$ extracts were washed with $\mathrm{H}_{2} \mathrm{O}$, dried, and evaporated to leave a brown oil that was dissolved in $\mathrm{H}_{2} \mathrm{O}(50$ $\mathrm{ml}), 37 \% \mathrm{HCl}(50 \mathrm{ml})$, and $\mathrm{MeOH}(100 \mathrm{ml})$. The mixture was refluxed for $4 \mathrm{~h}$. After cooling, precipitated crystals were collected, washed with $\mathrm{H}_{2} \mathrm{O}$, and recrystallized from $\mathrm{CHCl}_{3} / \mathrm{MeOH}$ to give $4\left(330 \mathrm{mg}, 14 \%\right.$ from 2), $\mathrm{mp} 250-252^{\circ}$ (dec); ir (Nujol) $v$ max 3240 (br, OH); uv $\lambda$ max $(\mathrm{MeOH})(\log \epsilon) 285(3.99), 236(\mathrm{sh}) \mathrm{nm}$, on addition of $\mathrm{NaOH} 299 ;{ }^{1} \mathrm{H} \mathrm{nmr}$ (DMSO-d $)_{6} \delta 1.3-$ $2.4(7 \mathrm{H}, \mathrm{m}), 2.6-2.8(1 \mathrm{H}, \mathrm{m}), 3.12(1 \mathrm{H}, \mathrm{m})$,
2.87 and $3.65($ each $1 \mathrm{H}, \mathrm{d}, J=16.0 \mathrm{~Hz},=\mathrm{C}$ $\mathrm{CH}_{2}-\mathrm{N}$ ), 3.48 and 3.68 (each $3 \mathrm{H}, \mathrm{s}, 2 \times \mathrm{OMe}$ ), 6.4-6.5 (4H, m, Ar-H), 6.52 and 6.71 (each $1 \mathrm{H}, \mathrm{d}, J=8.0 \mathrm{~Hz}, \mathrm{Ar}-\mathrm{H}), 8.7(2 \mathrm{H}, \mathrm{br}, 2 \times \mathrm{OH})$; $\mathrm{ms} \mathrm{m} / z$ (rel. int.) [M] ${ }^{+} 367$ (91), 298 (100), 267 (27), 235 (27), 137 (28), 70 (54); hrms $\mathrm{m} / z[\mathrm{M}]^{+}$ $367.17988) \mathrm{C}_{22} \mathrm{H}_{25} \mathrm{O}_{4} \mathrm{~N}$ requires 367.17847$)$, $298.12087\left(\mathrm{C}_{18} \mathrm{H}_{18} \mathrm{O}_{4}\right.$ requires 298.12051). The synthetic material was identical by tlc and ir spectra with an authentic sample.

Preparation of 2,6-DimethoXy-3,7-DIBENZYLOXYPHENANTHRO [9, 10-6]-INDOUZIDINE [5]. - A solution of $3(187 \mathrm{mg})$ in $\mathrm{MeCN}(10 \mathrm{ml})$ was added to a cold $\left(0^{\circ}\right)$ and stirred solution of $\mathrm{Tl}\left(\mathrm{CF}_{3} \mathrm{COO}\right)_{3}(205 \mathrm{mg})$ in $\mathrm{MeCN}(10 \mathrm{ml})$, followed by rapid addition of 10 drops of $\mathrm{BF}_{3} \cdot \mathrm{Et}_{2} \mathrm{O}$. The reaction mixture was stirred under $\mathrm{N}_{2}$ for 1.5 $h$ at $0^{\circ}$. The mixture was poured into $\mathrm{H}_{2} \mathrm{O}$ and was extracted with $\mathrm{CHCl}_{3}$. The combined extracts were washed with $\mathrm{H}_{2} \mathrm{O}$, then with $5 \%$ aqueous $\mathrm{NH}_{4} \mathrm{OH}$, dried, and evaporated. Crystallization of the residue from $\mathrm{CHCl}_{3} / \mathrm{MeOH}$ gave 5 (111 mg, 60\%), mp 199-201 ${ }^{\circ}$; ir (Nujol) $v \max 1620 ;$ uv $\lambda \max (\mathrm{MeOH})(\log \epsilon) 356$ (4.84), 340 (4.56), 322 (sh), 303 (4.33), 289 (3.41), 257 (3.23), 214 (sh) nm; ${ }^{1} \mathrm{H} \mathrm{nmr} \delta 1.68$ $2.56(6 \mathrm{H}, \mathrm{m}), 2.90(1 \mathrm{H}, \mathrm{m}), 3.3-3.5(2 \mathrm{H}, \mathrm{m})$, 3.55 and 4.49 (each $1 \mathrm{H}, \mathrm{d}, J=15.0 \mathrm{~Hz}$, $=\mathrm{C}$ $\mathrm{CH}_{2}-\mathrm{N}$ ), 4.06 and 4.08 (each $3 \mathrm{H}, \mathrm{s}, \mathrm{OMe}$ ), 5.33 and 5.41 (each $\left.2 \mathrm{H}, \mathrm{s}, \mathrm{OCH}_{2} \mathrm{Ph}\right), 7.22,7.34$, 7.64, and 7.88 (each $1 \mathrm{H}, \mathrm{s}, \mathrm{Ar}-\mathrm{H}), 7.35-7.63$ (10H, m, Ar-H); ms m/z (rel. int.) $[\mathrm{M}]^{+} 545$ (38), 476 (42), 385 (68), 91 (100); cims m/z $[\mathrm{M}+1]^{+}$546; hrms $\mathrm{m} / \mathrm{z} \quad[\mathrm{M}]^{+} \quad 545.2564$ $\left(\mathrm{C}_{36} \mathrm{H}_{35} \mathrm{NO}_{4}\right.$ requires 545.2572), 476.1986 $\left(\mathrm{C}_{32} \mathrm{H}_{28} \mathrm{O}_{4}\right.$ requires 476.2010), 385.1438 $\left(\mathrm{C}_{25} \mathrm{H}_{21} \mathrm{O}_{4}\right.$ requires 385.1438$), 91.0548\left(\mathrm{C}_{7} \mathrm{H}_{7}\right.$ requires 91.0547 ).

PRePaRATION OF 2,6-DIMETHOXY-3,7-DIHYDROXYPHENANTHRO $[9,10-6]$-INDOLIZIDINE [6]. - A mixture of 5 (43 mg) in $\mathrm{MeOH}(10 \mathrm{ml})$ and $10 \mathrm{~N} \mathrm{HCl}(5 \mathrm{ml})$ was refluxed under $\mathrm{N}_{2}$ for 3 $\mathrm{h}$. The mixture was allowed to stay overnight at room temperature. The precipitated material was recrystallized from $\mathrm{MeOH}$ to give $6 \cdot \mathrm{HCl}$ (30 $\mathrm{mg}, 95 \%)$, mp $250-252^{\circ}$ (dec); ir (Nujol) $v$ max 3530,3480 , and 3210 (br) $(\mathrm{OH}), 2720,2640$, and $2590\left(\gg \mathrm{N}^{+}-\mathrm{H}\right)$; uv $\lambda \max (\mathrm{MeOH})(\log \epsilon)$ 358 (3.16), 341 (3.27), 324 (sh), 304 (4.27), 290 (4.49), 256 (4.75), 238 (sh), $222(4.37) \mathrm{nm}$, on addition of $\mathrm{NaOH} 370,352,297,266,250$; ${ }^{1} \mathrm{H} \mathrm{nmr}$ (DMSO- $\left.d_{6}\right) \delta$ 1.85-2.3 (3H, m), 3.0$3.95(6 \mathrm{H}, \mathrm{m}), 4.00$ and 4.05 (each $3 \mathrm{H}, \mathrm{s}, \mathrm{OMe}$ ), 4.53 and 4.98 (each $1 \mathrm{H}, \mathrm{d}, J=15.0 \mathrm{~Hz},=\mathrm{C}$ $\mathrm{CH}_{2}-\mathrm{N}$ ), 7.17, 7.37, 7.92, and 8.07 (each $1 \mathrm{H}$, $\mathrm{s}, \mathrm{Ar}-\mathrm{H}), 9.54(2 \mathrm{H}, \mathrm{s}, \mathrm{OH})$. Free base [6]: $\mathrm{mp}$ $258-260^{\circ}$ (dec); ir (Nujol) v max 3410 (br, OH); ${ }^{1} \mathrm{H} \mathrm{nmr}\left(\mathrm{DMSO}-d_{6}\right) \delta 1.90-2.50(4 \mathrm{H}, \mathrm{m}), 2.90$ $3.20(3 \mathrm{H}, \mathrm{m}), 3.40-3.70(2 \mathrm{H}, \mathrm{m}), 4.0$ and 4.04 (each $3 \mathrm{H}, \mathrm{s}, 2 \times \mathrm{OMe}$ ), 4.12-4.77 (each $1 \mathrm{H}, \mathrm{d}$, 
$\left.J=15.0 \mathrm{~Hz},=\mathrm{C}_{-} \mathrm{CH}_{2}-\mathrm{N}\right), 7.20,7.35,7.91$, and 8.06 (each $1 \mathrm{H}, \mathrm{s}, \mathrm{Ar}-\mathrm{H}), 9.48(2 \mathrm{H}, \mathrm{s}$, $2 \times \mathrm{OH}$ ); ms $m / z$ (rel. int.) $[\mathrm{M}]^{+} 365$ (22), 296 (100), 281 (14); cims $m / z[\mathrm{M}+1]^{+} 366$; hrms $\mathrm{m} / \mathrm{z}$ $[\mathrm{M}]^{+} 365.1632\left(\mathrm{C}_{22} \mathrm{H}_{23} \mathrm{O}_{4} \mathrm{~N}\right.$ requires 365.1626$)$, $296.1050\left(\mathrm{C}_{18} \mathrm{H}_{16} \mathrm{O}_{4}\right.$ requires 296.1047).

PREPARATION OF ( \pm )-TYLOPHORINE [7].The hydrochloride of $6(28 \mathrm{mg})$ was dissolved in $10 \% \mathrm{NaOH}$. After acidification, the solution was basified with $\mathrm{NH}_{4} \mathrm{OH}$, extracted with $\mathrm{CHCl}_{3}$, and dried, and the solvent was removed. A solution of the residue in a mixture of $\mathrm{CHCl}_{3}(10 \mathrm{ml})$ and $\mathrm{MeOH}(10 \mathrm{ml})$ was treated with excess ethereal $\mathrm{CH}_{2} \mathrm{~N}_{2}$ (prepared from $\mathrm{N}, \mathrm{N}$-nitrosomethylurea), and the reaction mixture was left at room temperature for $40 \mathrm{~h}$. After decomposition of excess $\mathrm{CH}_{2} \mathrm{~N}_{2}$ with $10 \%$ HOAc, the solution was concentrated and $\mathrm{H}_{2} \mathrm{O}$ was added. The solution was basified with $\mathrm{NH}_{4} \mathrm{OH}$, extracted with $\mathrm{CHCl}_{3}$, dried, and evaporated. The residue was subjected to preparative tlc using $\mathrm{CHCl}_{3}-\mathrm{MeOH}$ (19:1) to give ( \pm )-tylophorine [7]; mp 263-265 (dec); uv $\lambda \max (\mathrm{MeOH})(\log \epsilon) 355$ (3.05), 339 (3.29), 324 (sh), 302 (4.26), 288 (4.51), 256 (4.80), 239 (sh), 221 (4.29) nm. The synthetic material was identical by tlc $\left(\mathrm{CHCl}_{3}-\mathrm{MeOH}\right.$
19:1), $\mathrm{mp}$, ir, and uv spectrometry with an authentic sample.

\section{ACKNOWLEDGMENTS}

We are very thankful to Dr. R.B. Herbert, University of Leeds, UK, for authentic samples of 4 and 7. Kinuko Iwasa thanks the Alexander von Humboldt Foundation, Bonn, Germany, for a scholarship.

\section{LITERATURE CITED}

1. R.B. Herbert, F.B. Jackson, and I.T. Nicolson, J. Chem. Soc., Perkin Trans. 1, 825 (1984).

2. Y. Ban and T. Oishi, Chem. Pharm. Bull., 6, 574 (1958).

3. C. Schöpf, E. Brass, E. Jacobi, W. Jorde, W. Mocnik, L. Neuroth, and W. Salzer, Liebigs Ann. Chem., 544, 30 (1940).

4. J.E. Cragg, R.B. Herbert, F.B. Jackson, C.J. Moody, and I.T. Nicolson, J. Chem. Soc., Perkin Trans. 1, 2477 (1982).

5. D.S. Bhakuni and V.K. Mangle, Tetrahedron, 37, 401 (1981).

Received 6 July 1987 